Research article

Open Access

\title{
Screening of Panamanian Plant Extracts for Pesticidal Properties and HPLC-Based Identification of Active Compounds
}

\author{
Niels Guldbrandsen ${ }^{1}$, Maria De Mieri ${ }^{1}$, Mahabir GuPtA ${ }^{2}$, \\ Tobias SEISER ${ }^{3}$, Christine WIEBE ${ }^{3}$, Joachim DICKHAUT ${ }^{3}$, \\ Rüdiger ReIngruber ${ }^{3}$, Oliver SORgENFreI ${ }^{3}$, Matthias HAMBURger ${ }^{*}{ }^{1}$
}

${ }^{1}$ Division of Pharmaceutical Biology, Department of Pharmaceutical Sciences, University of Basel, Klingelbergstrasse 50, CH-4056 Basel, Switzerland.

2 CIFLORPAN, College of Pharmacy, University of Panama, Apartado 0824-00172, Panama, Republic of Panama.

3 BASF SE, Carl-Bosch-Strasse 38, D-67056 Ludwigshafen, Germany.

* Corresponding author. E-mail: matthias.hamburger@unibas.ch (M. Hamburger)

Sci Pharm. 2015; 83: 353-367

doi:10.3797/scipharm.1410-10

Published: $\quad$ December $11^{\text {th }} 2014$

Accepted: $\quad$ December $11^{\text {th }} 2014$

Received: $\quad$ October $17^{\text {th }} 2014$

This article is available from: http://dx.doi.org/10.3797/scipharm.1410-10

(c) Guldbrandsen et al.; licensee Österreichische Apotheker-Verlagsgesellschaft m. b. H., Vienna, Austria.

This is an Open Access article distributed under the terms of the Creative Commons Attribution License (http://creativecommons.org/licenses/by/3.0/), which permits unrestricted use, distribution, and reproduction in any medium, provided the original work is properly cited.

\begin{abstract}
A library of 600 taxonomically diverse Panamanian plant extracts was screened for fungicidal, insecticidal, and herbicidal activities. A total of 19 active extracts were submitted to HPLC-based activity profiling, and extracts of Bocconia frutescens, Miconia affinis, Myrcia splendens, Combretum aff. laxum, and Erythroxylum macrophyllum were selected for the isolation of compounds. Chelerythrine (2), macarpine (3), dihydrosanguinarine (5), and arjunolic acid (8) showed moderate-to-good fungicidal activity. Myricetin-3-O-(6"-O-galloyl)- $\beta$ galactopyranoside (13) showed moderate insecticidal activity, but no compound with herbicidal activity was identified.
\end{abstract}

\section{Keywords}

Panamanian plant extracts - HPLC-based activity profiling • Fungicide • Insecticide • Herbicide

\section{Introduction}

Plants and their extracts have been used for a long time for crop protection. They are a promising source for pesticides due to the fact that many plants produce secondary 
metabolites to defend against pests. However, after evolvement of the chemical synthesis of pesticides, the importance of botanical sources decreased [1]. But still, botanical sources play an important role especially in developing countries, where there is a rich indigenous knowledge of using plants and plant extracts for crop protection [2].

Alternatively to ethnobotanical sources, the investigation of taxonomically highly diverse and unique plants has been applied successfully in drug discovery [3]. Globally, some 25 so-called biodiversity hotspots are identified combining high diversity with a high degree of endemism. The ranking is based on the number of species per $100,000 \mathrm{~km}^{2}$ [4]. Panama is one of the biodiversity hotspots with a highly diverse flora. Panama and its environment possess the highest diversity of plant species in the world and belong to the 25 most plantrich countries, ranking in fourth place in the North American continent $[5,6]$. Despite the small surface area, its flora comprises 9,893 vascular plant species including 1,327 $(13.4 \%)$ endemic plants $[7,8]$. Gupta and collaborators have shown in three reviews that the flora of Panama is extremely rich in bioactive compounds and still represents an untapped source of novel compounds for pharmaceutical, agrochemical, and cosmetic industries [9-11].

In an FP7 framework project aiming at discovering new agrochemical compounds, we screened 600 Panamanian plant extracts for fungicidal, insecticidal, and herbicidal properties. Their agrochemical potential was evaluated at BASF. A primary, highly automated screening in 96-well plates at a concentration of 2,500 ppm was done in three screens. In these assays, the fungicidal activity is tested on four pathogenic plant fungi and a ratio of the growth rate to standard is estimated by an optical density measurement. The herbicidal activity is evaluated on three plants in post- and pre-emergence, while the insecticidal activity is assessed on five different insects from four families. These screening systems are highly miniaturized and automated to provide high-throughput evaluations. Whole plants are substituted by leaf fragments and insect eggs or small larvae are used as models for real life pests. As a result, these assays are very sensitive in order to not miss any interesting activity. Follow-up tests with bigger plants in pots are then used to further characterize these initial hits to identify compounds with market potential. Selected extracts from the primary screens were submitted to a process called HPLC-based activity profiling, which combines physicochemical data recorded online with biological information in parallel to time-based HPLC fractionation $[12,13]$. Most of the active constituents were isolated, characterized, and screened for pesticidal activity.

\section{Results and Discussion}

A library of 600 extracts prepared from Panamanian plants was screened for fungicidal, insecticidal, and herbicidal activity. A total of 19 extracts fulfilled previously defined activity criteria, which were: a ratio of $\geq 0.75$ for fungicidal, $\geq 50 \%$ activity against larvae and adult insects for insecticidal, and $\geq 50 \%$ (Agrostis stolonifera and Poa annua) or $\geq 80 \%$ (Matricaria inodora) for herbicidal activity (Tab. 1S, Supporting Information). A flow chart illustrating the further progression of samples is shown in Fig. 1. Active extracts were submitted to HPLC-based activity profiling $[12,13]$, and collected micro-fractions were submitted to screening in the respective assays. Based on the above activity criteria, 12 extracts were prioritized. With the aid of chromatographic and activity profiles, five extracts were then selected for a detailed investigation. Among these, two extracts were chosen for 
their fungicidal (Fig. 2), one extract for its insecticidal (Fig. 3), and two extracts for herbicidal activity (Fig. 4).

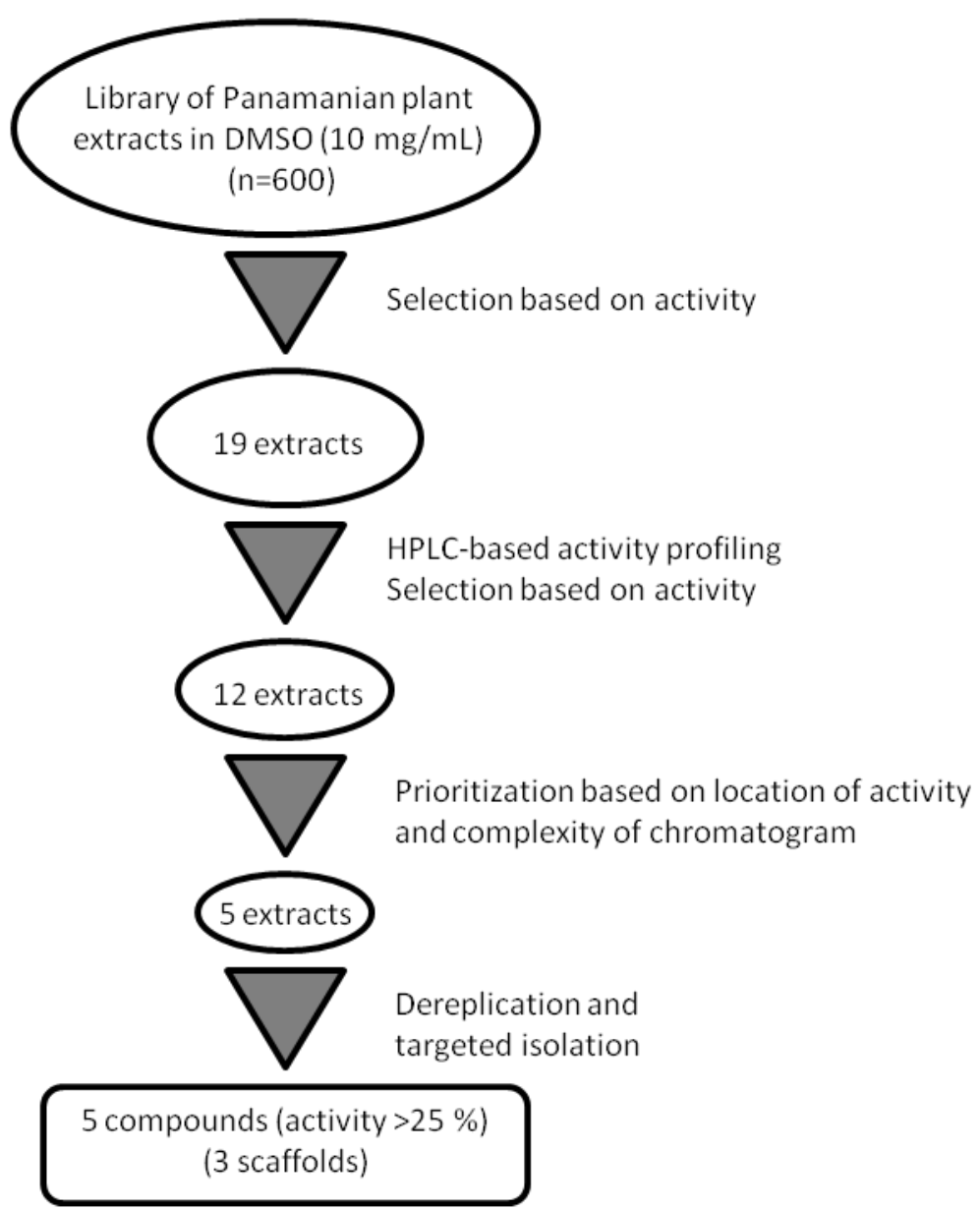

Fig. 1. Workflow for the discovery of agrochemicals from Panamanian plant extracts

The methanolic extract of Bocconia frutescens (Papaveraceae) showed fungicidal activity against Magnaporte oryzae in time windows corresponding to major UV-absorbing peaks (Fig. 2A). Two of the active fractions and one additional fraction also showed activity against other fungal strains (Fig 1S, Supporting Information). The two early-eluting main peaks were identified as sanguinarine (1) [14] and chelerythrine (2) [14] (Fig. 5). Compound 2 showed moderate activity against Botryotinia fuckeliana, $M$. oryzae, Phytophtora infestans, and Septoria tritici. The late-eluting active peaks were identified as oxysanguinarine (4) [15] and dihydrosanguinarine (5) [14]. Compound 4 showed no fungicidal activity, while 5 was active against $M$. oryzae, $P$. infestans, and $S$. tritici. Macarpine (3) [16] was in a microfraction active against $P$. infestans (Fig 1S B, Supporting Information). The purified compound showed good fungicidal activity against $P$. infestans and $M$. oryzae. With the exception of $\mathbf{4}$, the compounds had been previously reported from $B$. frutescens $[17,18]$. 

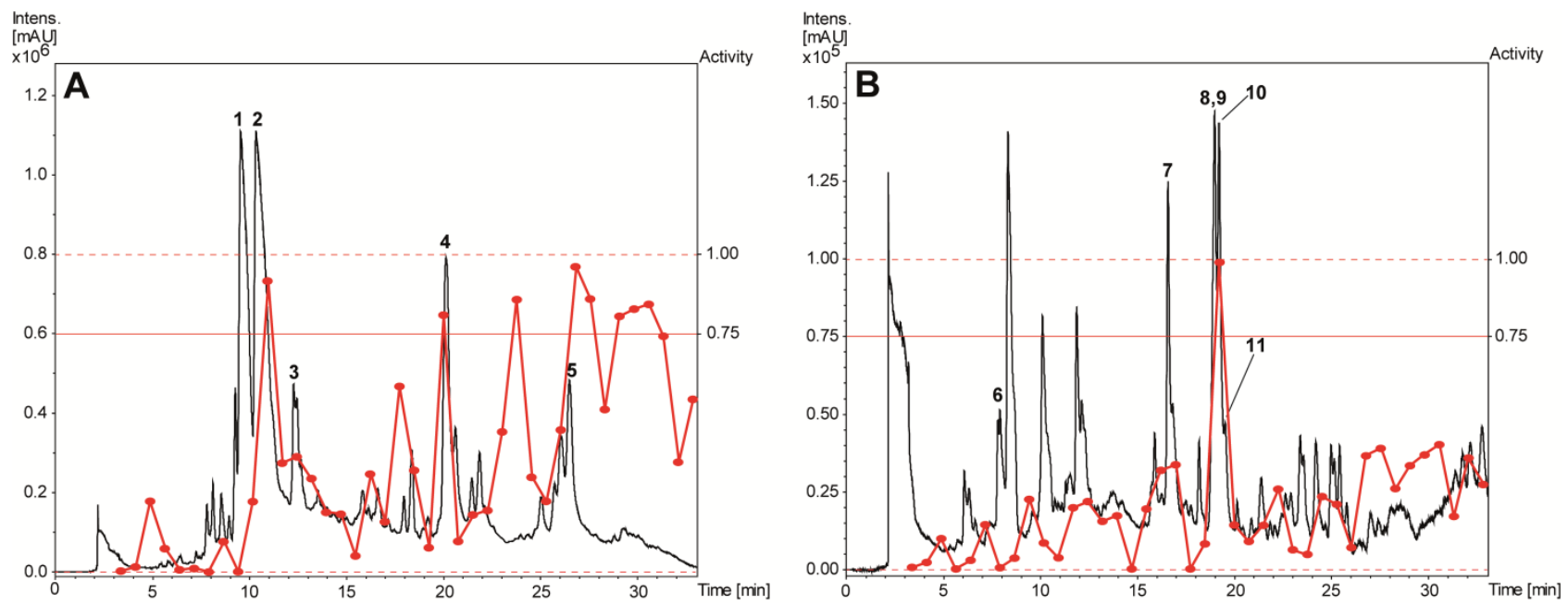

Fig. 2. HPLC-based activity profiling of selected plant extracts for fungicidal activity against $M$. oryzae. SunFire $C_{18}$ column (150 x $10 \mathrm{~mm}$ i.d., $\left.5 \mu \mathrm{m}\right) ; 5-100 \%$ $\mathrm{MeCN} / 0.1 \%$ aqueous formic acid in $30 \mathrm{~min}(\mathrm{~A})$, and $50-100 \% \mathrm{MeCN} / 0.1 \%$ aqueous formic acid in $30 \mathrm{~min}(\mathrm{~B}), 4 \mathrm{~mL} / \mathrm{min}$; detection: 200-500 nm, maxplot. (A) Bocconia frutescens (MeOH stem extract). (B) Miconia affinis (EtOAc stem extract). Activity of microfractions are shown as a red curve

The profile of the ethyl acetate extract of Miconia affinis (Melastomataceae) showed one fraction active against $M$. oryzae (Fig. 2B) and S. tritici. This fraction consisted of three strongly UV-absorbing peaks (9-11) and one non-UV active compound (8) (Fig. 5). Peak 10 was purified and identified as $3^{\prime}, 4^{\prime}, 5^{\prime}$-tri-O-methyl-3,4-O,O-methyleneflavellagic acid [19]. UV and MS data of the other two UV-absorbing peaks were indicative of 3,4:3',4'bis(O-O-methylene)ellagic acid (9) [20] and 3',4'-di-O-methyl-3,4-O,O-methyleneellagic acid (11) [19], and were not further pursued. Arjunolic acid (8) [21] was purified by normal phase flash chromatography, and its presence in the active fraction was confirmed by HPLC-DAD-ELSD. Compound $\mathbf{8}$ was active against $M$. oryzae and S. tritici. In previous studies [22, 23], the fungicidal activity of arjunolic acid (8) in a mixture with asiatic acid was reported, while in the current study the activity of purified $\mathbf{8}$ was confirmed. Two additional compounds outside of the active time window were also isolated and identified as $\beta$-hydroxypropiovanillone (6) [24] and 3'-O-methyl-3,4-O,O-methyleneellagic acid (7) [25]. All compounds are reported for the first time from $M$. affinis, since no phytochemical studies have been conducted on this species before.

A broad hump in the chromatogram of the methanolic extract of Myrcia splendens (Myrtaceae) indicated the presence of tannins (Fig. 3). However, two distinct windows of insecticidal activity against Ceratitis capitata were seen between $t_{R} 7-10 \mathrm{~min}$. After largescale extraction, peaks $\mathbf{a}$ and $\mathbf{b}$ depleted, and $\mathbf{c}$ even disappeared, while peak $\mathbf{1 5}$ was extremely enriched in the crude extract. Prior to HPLC purification, the extract was separated over polyamide yielding five tannin-depleted fractions (Fig 2S, Supporting Information). From the first active time-window, compound $\mathbf{1 3}$ was isolated and identified as myricetin-3-O-(6"-O-galloyl)- $\beta$-galactopyranoside [26] (Fig. 5). The compound showed weak activity against $C$. capitata at $2500 \mathrm{ppm}$. From the second active time window, inactive myricitrin (15) [27] and quercitrin (16) [28] were isolated. Additional compounds isolated from fractions outside of the active time windows were gallic acid (12), myricetin- 
3-O- $\beta$-galactopyranoside (14) [29], and myricetin (17) [30]. Compound 15 had been previously reported from $M$. splendens [31], while the other compounds were new for the species.

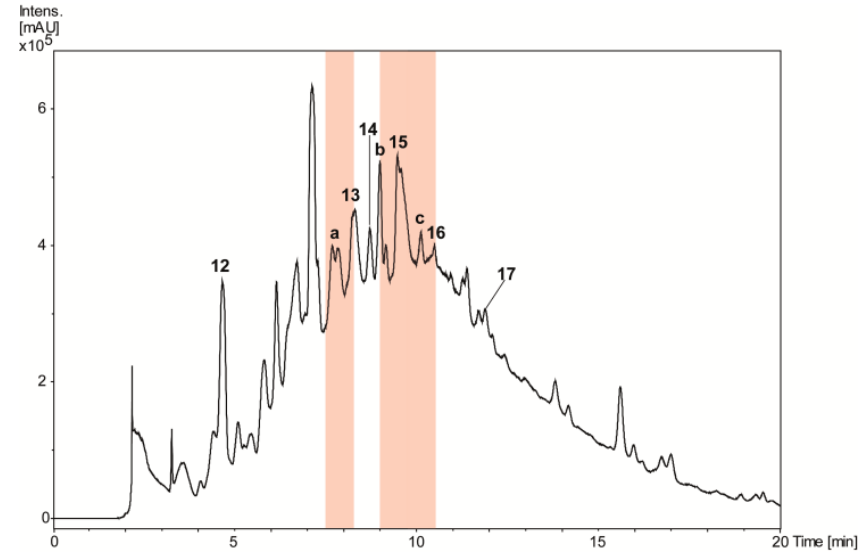

Fig. 3. HPLC-based activity profiling of a MeOH leaf extract of Myrcia splendens for insecticidal activity against Ceratitis capitata. SunFire $\mathrm{C}_{18}$ column $(150 \times 10$ $\mathrm{mm}$ i.d., $5 \mu \mathrm{m}$ ); 5-100\% MeCN/0.1\% aqueous formic acid in $30 \mathrm{~min} ; 4$ $\mathrm{mL} / \mathrm{min}$; time-based fractionation; detection: 200-500 nm, maxplot. Windows of insecticidal activity are highlighted in red

The methanolic leaf extract of Combretum affinis laxum (Combretaceae) showed herbicidal activity against pre-emergent Agrostis stolonifera (Fig 4A), and post-emergent Poa annua in the time range of peak 21. Tannins in the extract were removed by filtration over polyamide, and 2"-O-galloylmyricitrin (20) [32], 3"-O-galloylmyricitrin (21) [32], 2"-Ogalloylquercitrin (22) [33], and 3"-O-galloylquercitrin $(23)$ [34, 35] were isolated by HPLC from fractions PA4 and PA5 (Fig 3S, Supporting Information). Compound 21 showed no significant herbicidal activity. Ellagic acid (18) was obtained from PA5 and confirmed by spiking with a commercial sample. In addition, inactive compounds 12, 15, 16 were isolated, together with mearnsitrin (19) [36]. All compounds were new for C. aff. laxum, since no phytochemical data have been previously reported on this species.

The extract of Erythroxylum macrophyllum (Erythroxylaceae) showed distinct activity against post-emergent $M$. inodora, even though the broad hump in the HPLC chromatogram was indicative of tannins (Fig 4B). In time windows $t_{R}$ 3-5 min and $t_{R}$ 15-16 min, the activity could not be correlated to a peak in the UV or MS traces. The extract was filtered over polyamide, and five tannin-depleted fractions were obtained (Fig 4S, Supporting Information). Compounds in the active time windows were purified by HPLC, and identified as neochlorogenic acid (24) [37, 38], protocatechuic acid (25) [39], quercetin-3,7-O- $\alpha$-dirhamnopyranoside (26) [40], 5-O- $\beta$-glucopyranosylombuin-3-O- $\beta$ rutinoside (27) [41], and rutin (28) [42]. However, none of the flavonoids showed activity in the herbicidal assay when tested as pure compounds. In addition, 16 and ombuin-3-O- $\beta$ rutinoside (29) [41] were isolated. All compounds are reported here for the first time from E. macrophyllum. 

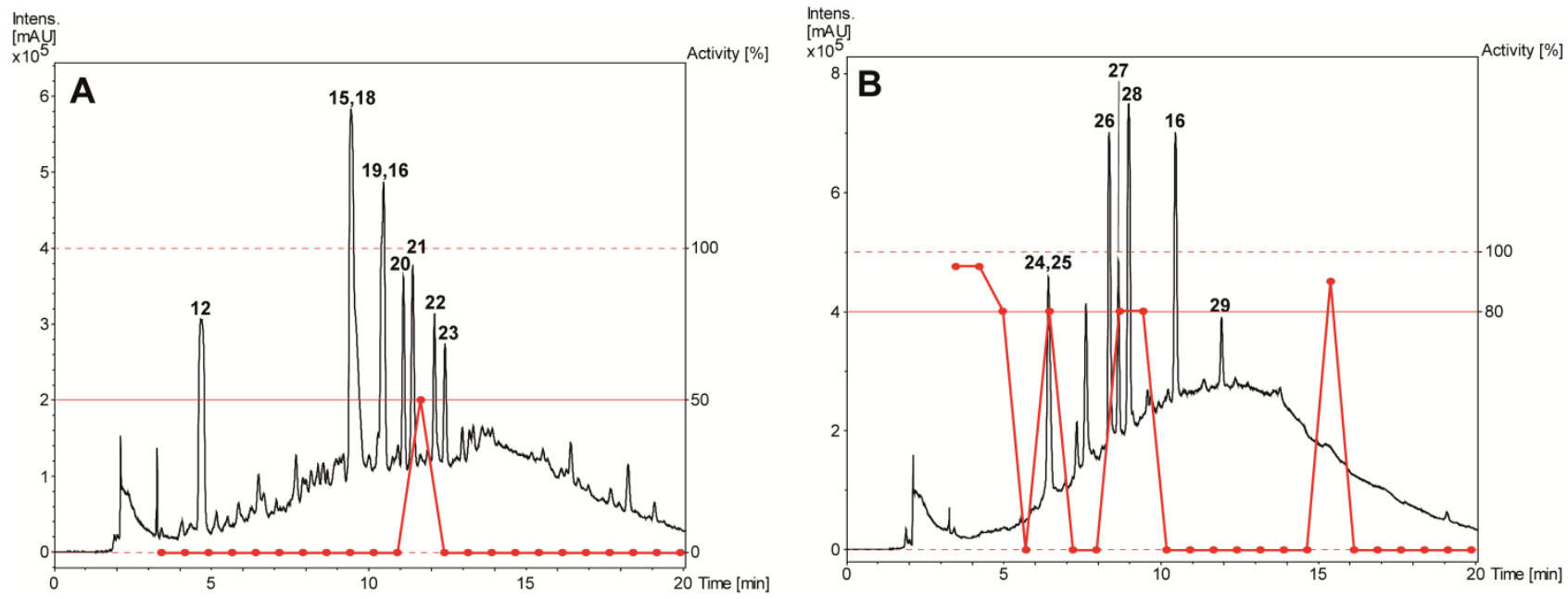

Fig. 4. HPLC-based activity profiling of selected plant extracts for herbicidal activity. SunFire $\mathrm{C}_{18}$ column (150 x $10 \mathrm{~mm}$ i.d., $\left.5 \mu \mathrm{m}\right) ; 5-100 \% \mathrm{MeCN} / 0.1 \%$ aqueous formic acid in $30 \mathrm{~min} ; 4 \mathrm{~mL} / \mathrm{min}$; time-based fractionation; detection: 200-500 $\mathrm{nm}$, maxplot. (A) Combretum aff. laxum (MeOH leaf extract) against preemergent Agrostis stolonifera. (B) Erythroxylum macrophyllum (MeOH leaf extract) against post-emergent Matricaria inodora. Activity of microfractions is shown as red curves

In total, four fungicidal and one weakly insecticidal natural product were discovered by means of HPLC-based activity profiling. In contrast, none of the compounds purified from active time windows of $C$. aff. laxum and $E$. macrophyllum showed herbicidal activity. The activity in these time windows may have been, at least in part, due to the presence of tannins. This might have been confirmed by a retest for activity of tannin-depleted extracts. The example of fungicidal compounds showed that the profiling approach could be efficiently used for discovery of bioactive compounds of possible agrochemical interest.

Tab. 1. Activity of isolated and tested compounds

\begin{tabular}{|c|c|c|}
\hline Compound & Indication & Activity $^{\mathrm{a}}$ \\
\hline Chelerythrine (2) & Fungicide & + \\
\hline Macarpine (3) & Fungicide & ++ \\
\hline Oxysanguinarine (4) & Fungicide & - \\
\hline Dihydrosanguinarine (5) & Fungicide & ++ \\
\hline Arjunolic acid (8) & Fungicide & ++ \\
\hline Myricetin-3-O-(6"-O-galloyl)- $\beta$-galactopyranoside (13) & Insecticide & + \\
\hline Myricitrin (15) & Insecticide & - \\
\hline Quercitrin (16) & Insecticide & - \\
\hline 3"-O-Galloylmyricitrin (21) & Herbicide & - \\
\hline Neochlorogenic acid (24) & Herbicide & - \\
\hline Protocatechuic acid (25) & Herbicide & - \\
\hline Quercitrin-7-O-a-rhamnopyranoside (26) & Herbicide & - \\
\hline 5-O- $\beta$-Glucopyranosylombuin-3-O- $\beta$-rutinoside (27) & Herbicide & - \\
\hline Rutin (28) & Herbicide & - \\
\hline
\end{tabular}


<smiles></smiles>

$1 \mathrm{R}^{1}, \mathrm{R}^{2}=-\mathrm{CH}_{2^{-}}, \mathrm{R}^{3}=\mathrm{R}^{4}=\mathrm{H}$ $2 R^{1}=R^{2}=C_{3}, R^{3}=R^{4}=H$ $3 \mathrm{R}^{1}, \mathrm{R}^{2}=-\mathrm{CH}_{2^{-}}, \mathrm{R}^{3}=\mathrm{R}^{4}=\mathrm{OCH}_{3}$<smiles>[R20]c1c([R])c2oc(=O)c3cc4c(c5oc(=O)c(c1[R2])c2c53)OCO4</smiles>

$7 \mathrm{R}^{1}=\mathrm{CH}_{3}, \mathrm{R}^{2}=\mathrm{R}^{3}=\mathrm{H}$ $9 \mathrm{R}^{1,} \mathrm{R}^{2}=-\mathrm{CH}_{2^{-}}, \mathrm{R}^{3}=\mathrm{H}$ $10 \mathrm{R}^{1}=\mathrm{R}^{2}=\mathrm{CH}_{3}, \mathrm{R}^{3}=\mathrm{OCH}_{3}$

$11 \mathrm{R}^{1}=\mathrm{R}^{2}=\mathrm{CH}_{3}, \mathrm{R}^{3}=\mathrm{H}$<smiles></smiles>

$13 \mathrm{R}=$ galloyl $14 \mathrm{R}=\mathrm{H}$<smiles>[R]C1([R])c2c(ccc3c2OCO3)-c2ccc3cc4c(cc3c2N1C)OCO4</smiles>

$4 R^{1}, R^{2}=0$ $5 R^{1}=R^{2}=H$

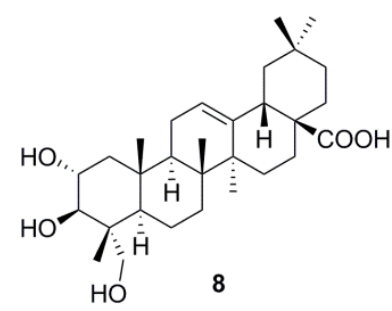<smiles>[R]Oc1c(-c2cc([R])c(OCC)c(O)c2)oc2cc([R20])cc(O)c2c1=O</smiles>

$15 \mathrm{R}^{1}=\mathrm{R}^{4}=\mathrm{H}, \mathrm{R}^{2}=\mathrm{OH}, \mathrm{R}^{3}=\mathrm{Rha}$ $16 R^{1}=R^{2}=R^{4}=H, R^{3}=R h a$ $17 \mathrm{R}^{1}=\mathrm{R}^{3}=\mathrm{R}^{4}=\mathrm{H}, \mathrm{R}^{2}=\mathrm{OH}$ $19 \mathrm{R}^{1}=\mathrm{CH}_{3}, \mathrm{R}^{2}=\mathrm{OH}, \mathrm{R}^{3}=\mathrm{Rha}, \mathrm{R}^{4}=\mathrm{H}$ $26 R^{1}=R^{2}=H, R^{3}=R^{4}=R h a$<smiles>COc1cc(C(=O)CCO)ccc1O</smiles><smiles>[R]c1cc(C(=O)O)cc(O)c1O</smiles>

$12 \mathrm{R}=\mathrm{OH}$ $25 \mathrm{R}=\mathrm{H}$<smiles>[R1]O[C@H]1[C@H](O)[C@@H](C)OC(Oc2c(-c3cc([R])c(O)c(O)c3)oc3cc(O)cc(O)c3c2=O)[C@@H]1[R2]</smiles>

$20 \mathrm{R}^{1}=\mathrm{OH}, \mathrm{R}^{2}=$ galloyl, $\mathrm{R}^{3}=\mathrm{H}$ $21 \mathrm{R}^{1}=\mathrm{OH}, \mathrm{R}^{2}=\mathrm{H}, \mathrm{R}^{3}=$ galloyl $22 \mathrm{R}^{1}=\mathrm{R}^{3}=\mathrm{H}, \mathrm{R}^{2}=$ galloyl $23 R^{1}=R^{2}=H, R^{3}=$ galloyl<smiles>O=C(/C=C/c1ccc(O)c(O)c1)OC1C[C@](O)(C(=O)O)C[C@H](O)C1O</smiles>

24<smiles>O=C1Oc2c(O)c(O)cc3c2c(=O)oc2c(O)c(O)cc1c23</smiles>

18

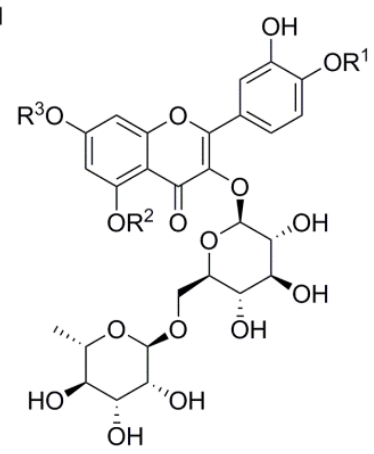

$27 \mathrm{R}^{1}=\mathrm{R}^{3}=\mathrm{CH}_{3}, \mathrm{R}^{2}=\mathrm{GlC}$ $28 R^{1}=R^{2}=R^{3}=H$ $29 \mathrm{R}^{1}=\mathrm{R}^{3}=\mathrm{CH}_{3}, \mathrm{R}^{2}=\mathrm{H}$

Fig. 5. Structures of identified compounds: sanguinarine (1), chelerythrine (2), macarpine (3), oxysanguinarine (4), dihydrosanguinarine (5), $\beta$-hydroxypropiovanillone (6), 3'-O-methyl-3,4-O,O-methyleneellagic acid (7), arjunolic acid (8), 3,4:3',4'-bis(O-O-methylene)ellagic acid (9), 3',4',5'-tri-O-methyl-3,4O,O-methyleneflavellagic acid (10), 3'4'-di-O-methyl-3,4-O,O-methyleneellagic acid (11), gallic acid (12), myricetin-3-O-(6"-O-galloyl)- $\beta$-galactopyranoside (13), myricetin-3-O- $\beta$-galactopyranoside (14), myricitrin (15), quercitrin (16), myricetin (17), ellagic acid (18), mearnsitrin (19), 2"-O-galloylmyricitrin (20), 3"'-Ogalloylmyricitrin (21), 2"-O-galloylquercitrin (22), 3"'-O-galloylquercitrin (23), neochlorogenic acid (24), protocatechuic acid (25), quercitrin-7-O- $\alpha$ rhamnopyranoside (26), 5-O- $\beta$-glucopyranosylombuin-3-O- $\beta$-rutinoside (27), rutin (28), and ombuin-3-O- $\beta$-rutinoside (29) 


\section{Experimental}

\section{General Experimental Procedures}

Quercitrin (16, $\geq 98 \%$ ) and polyamide (particle size: 0.05-0.16 mm) were purchased from Carl Roth. Rutin (27, $\geq 94 \%)$ was from Sigma-Aldrich. HPLC-grade acetonitrile and methanol (Reuss Chemie AG), and distilled water were used for HPLC separations. Preparative HPLC was carried out on an LC 8A preparative liquid chromatograph equipped with an SPD-M10A VP PDA detector (all Shimadzu). A SunFire $\mathrm{C}_{18}$ column (150 x $30 \mathrm{~mm}$ i.d., $5 \mu \mathrm{m}$; Waters) connected to a pre-column $(10 \times 30 \mathrm{~mm})$ was used, at a flow rate of $20 \mathrm{~mL} / \mathrm{min}$. HPLC-based activity profiling was performed on an Agilent 1100 system equipped with a PDA detector. A SunFire $C_{18}$ column $(150 \times 10 \mathrm{~mm}$ i.d., $5 \mu \mathrm{m}$; Waters $)$ connected to a pre-column $(10 \times 10 \mathrm{~mm})$ was used, at a flow rate of $4 \mathrm{~mL} / \mathrm{min}$. Time-based fractions were collected with a Gilson FC204 fraction collector. Analytical HPLC-DADELSD chromatography was performed on a Waters 2690 Alliance system equipped with a 996 PDA detector and an Alltech ELSD 2000ES. A SunFire $C_{18}$ column $(150 \times 3 \mathrm{~mm}$ i.d., $3.5 \mu \mathrm{m}$; Waters) connected to a pre-column $(10 \times 3 \mathrm{~mm})$ was used, at a flow rate of 0.4 $\mathrm{mL} / \mathrm{min}$. Silica gel flash chromatography was performed on an Interchim Puri Flash 4100 system. ESI-MS spectra were obtained on an Esquire 3000 Plus ion trap mass spectrometer (Bruker Daltonics). ESI-TOF-MS spectra were recorded in positive mode on a Bruker microTOF ESI-MS system. Mass calibration was done with a reference solution of $0.1 \%$ sodium formate in 2-propanol/water (1:1) containing $5 \mathrm{mM} \mathrm{NaOH}$. NMR spectra were recorded on an Avance III $500 \mathrm{MHz}$ spectrometer (Bruker BioSpin) equipped with a 1-mm TXI microprobe and a 5-mm BBO probe.

\section{Plant Material}

Stems of Bocconia frutescens L. were collected in August 2012 in El Valle de Antón, La Mesa, Coclé, Panama. Stems of Miconia affinis DC. were collected in October 2007 in Parque Nacional Chagres, section Cerro Azul, Panama. Leaves of Myrcia splendens (SW.) DC. were collected in June 2012 in Parque Nacional Altos de Campana, Panama. Stems of Combretum affinis laxum Jacq. were collected in November 1996 in Punta Muñiz, Parque Nacional Coiba, Panama. Leaves of Erythroxylum macrophyllum Kunth were collected in January 1993 in Parque Nacional Altos de Campana, Panama. The plant material was identified by Alex Espinosa, and voucher specimens have been deposited at the Herbarium of the University of Panama (PMA). Also, vouchers are kept at the Division of Pharmaceutical Biology, University of Basel: Nr. 844 (B. frutescens), Nr. 845 (M. affinis), Nr. 901 (M. splendens), Nr. 866 (C. aff. laxum), and Nr. 867 (E. lucidum).

\section{HPLC-Based Activity Profiling}

Extracts dissolved in DMSO $(50 \mathrm{mg} / \mathrm{mL})$ were separated by semi-preparative HPLC. Two aliquots of $200 \mu \mathrm{L}$ corresponding to $10 \mathrm{mg}$ extract were injected. For two ethyl acetate extracts (stems of Bocconia frutescens and leaves of Clusia uvitana), a gradient of 50$100 \% \mathrm{MeCN}$ in $30 \mathrm{~min}$ in $0.1 \%$ aqueous formic acid was used. For the other extracts, a gradient of $5-100 \% \mathrm{MeCN}$ in $30 \mathrm{~min}$ in $0.1 \%$ aqueous formic acid was employed. Fractions of $0.75 \mathrm{~min}$ were collected from $\mathrm{t}=3 \mathrm{~min}$ to $\mathrm{t}=33 \mathrm{~min}$. Fractions were transferred into 96 deepwell plates, evaporated, and submitted to screening. 


\section{Extraction and Isolation}

Powdered stems of $B$. frutescens $(1,002.0 \mathrm{~g})$ were percolated with $15 \mathrm{~L} \mathrm{MeOH}$ to afford $45.9 \mathrm{~g}$ of extract. A portion $(10.0 \mathrm{~g})$ of the extract was submitted to silica gel flash chromatography using $\mathrm{CH}_{2} \mathrm{Cl}_{2}$ for $30 \mathrm{~min}$, followed by a gradient of $0-5 \%$ in $60 \mathrm{~min}, 5 \%$ over $30 \mathrm{~min}, 5-10 \%$ in $30 \mathrm{~min}$, and $10 \% \mathrm{MeOH}$ in $\mathrm{CH}_{2} \mathrm{Cl}_{2}$ over $60 \mathrm{~min}$, at a flow rate of 50 $\mathrm{mL} / \mathrm{min}$. Eight fractions (Fr. 1-8) were combined on the basis of TLC patterns. Fr. 1 (409.3 mg) was separated by preparative HPLC ( $80 \%$ aqueous MeCN with $0.1 \%$ formic acid) to afford dihydrosanguinarine $\left(5,231.7 \mathrm{mg}, \mathrm{t}_{\mathrm{R}} 11.4 \mathrm{~min}\right)$. A portion $(501.9 \mathrm{mg})$ of $\mathrm{Fr}$. 7 (1620.1 mg) was separated by flash chromatography on silica gel using hexane (solvent A) and ethyl acetate (solvent $B$ ) at a flow rate of $10 \mathrm{~mL} / \mathrm{min}$. A gradient of $0-19 \% \mathrm{~B}$ in 19 min, 19\% B over $5 \mathrm{~min}, 19-40 \%$ B in $21 \mathrm{~min}$, and $40-100 \%$ B in $41 \mathrm{~min}$, followed by $100 \%$ B over 81 min yielded six fractions (Fr. 7a-7f). Colorless crystals precipitated from Fr. 7d$7 \mathrm{f}$, and were recrystallized from ethyl acetate $/ \mathrm{CH}_{2} \mathrm{Cl}_{2}$ to afford oxysanguinarine $(4,18.6$ $\mathrm{mg}$ ). Fractions $7 b-7 d$ were submitted to preparative HPLC (aqueous MeCN with 0.025\% TFA). Sanguinarine $\left(\mathbf{1}, 67.0 \mathrm{mg}, \mathrm{t}_{\mathrm{R}} 8.1 \mathrm{~min}\right)$ was obtained from Fr. $7 \mathrm{~b}(123.3 \mathrm{mg})$ using $32 \% \mathrm{MeCN}$. For Fr. 7c (163.4 mg) and 7d (123.2 mg), 35\% MeCN was used to afford chelerythrine $\left(2,105.1 \mathrm{mg}, \mathrm{t}_{\mathrm{R}} 7.6 \mathrm{~min}\right)$ and macarpine $\left(3,9.5 \mathrm{mg}, \mathrm{t}_{\mathrm{R}} 13.6 \mathrm{~min}\right)$.

Powdered stems of $M$. affinis $(1,001.2 \mathrm{~g})$ were percolated with ethyl acetate $(11 \mathrm{~L})$ to afford $4.5 \mathrm{~g}$ of extract. A portion $(2.9 \mathrm{~g})$ of the extract was submitted to silica gel flash chromatography using $\mathrm{CH}_{2} \mathrm{Cl}_{2}$ (solvent $\mathrm{A}$ ) and ethyl acetate (solvent $\mathrm{B}$ ). A gradient of 0$100 \%$ B in $120 \mathrm{~min}$, followed by $100 \%$ B over 30 min was used, at a flow rate of $40 \mathrm{~mL} / \mathrm{min}$ to afford 12 fractions (Fr. 1-12). Fr. 5 (370.1 mg) was separated by preparative HPLC using $45 \%$ aqueous MeCN to give 3'-O-methyl-3,4-O,O-methyleneellagic acid (7, $1.8 \mathrm{mg}$,

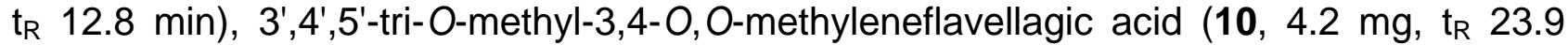
min), and a mixture of 3'4'-di-O-methyl-3,4-O,O-methyleneellagic acid (11, $\left.t_{R} 24.9 \mathrm{~min}\right)$ and 10. From Fr. 8 (102.5 mg), a mixture containing 3,4:3',4'-bis(O,O-methylene)ellagic acid (9) precipitated after dissolution in DMSO. The supernatant of Fr. 8 was submitted to preparative HPLC (15\% aqueous MeCN) to afford $\beta$-hydroxypropiovanillone $\left(6,1.4 \mathrm{mg}, \mathrm{t}_{R}\right.$ $12.9 \mathrm{~min}$ ). Fr. 12 (396.7 mg) was separated by flash chromatography on silica gel, using $\mathrm{CH}_{2} \mathrm{Cl}_{2}$ (solvent $\mathrm{A}$ ) and $\mathrm{MeOH}$ (solvent $\mathrm{B}$ ) as the mobile phase. $\mathrm{A}$ gradient of $0-6 \% \mathrm{~B}$ in 8 $\mathrm{min}, 6 \% \mathrm{~B}$ over $22 \mathrm{~min}$, and $6-100 \% \mathrm{~B}$ in $10 \mathrm{~min}$ afforded arjunolic acid $(\mathbf{8}, 241.1 \mathrm{mg})$.

Powdered leaves of $M$. splendens $(801.8 \mathrm{~g})$ were percolated with $\mathrm{MeOH}(12 \mathrm{~L})$ to afford $217.0 \mathrm{~g}$ of extract. A portion (10.2 g) of the extract was redissolved in $200 \mathrm{~mL} \mathrm{MeOH}$ and separated on a polyamide column (50-160 $\mu \mathrm{m}, 200 \mathrm{~g}$; Roth) with $\mathrm{MeOH}$ as eluent. Three fractions (PA1-PA3) of $1 \mathrm{~L}$ each, one fraction (PA4) of $3 \mathrm{~L}$, and one fraction (PA5) of $5 \mathrm{~L}$ were collected. Fraction PA2 $(682.4 \mathrm{mg})$ was separated by preparative HPLC using $25 \%$ aqueous MeCN to afford myricitrin $\left(15, t_{R} 7.0 \mathrm{~min}\right)$ and quercitrin $\left(16,5.0 \mathrm{mg}, \mathrm{t}_{\mathrm{R}} 10.2 \mathrm{~min}\right)$. Final purification of 15 was achieved with $20 \%$ aqueous $\mathrm{MeCN}$ (134.5 mg, $13.7 \mathrm{~min}$ ). Preparative HPLC of fraction PA3 (19\% aqueous MeCN) yielded myricetin-3-O- $\beta$ galactopyranoside (14, $\left.\mathrm{t}_{\mathrm{R}} 10.2 \mathrm{~min}\right)$ and 15 (7.8 $\left.\mathrm{mg}, \mathrm{t}_{\mathrm{R}} 15.9 \mathrm{~min}\right) .14$ was finally purified by semi-preparative HPLC using $17 \% \mathrm{MeCN}$ in $0.05 \%$ aqueous formic acid $\left(4.2 \mathrm{mg}, \mathrm{t}_{\mathrm{R}} 7.6\right.$ min). Fraction PA5 was separated by preparative HPLC with a gradient of MeCN in $0.05 \%$ aqueous formic acid (5-40\% over $15 \mathrm{~min})$. Gallic acid (12, $\left.8.9 \mathrm{mg}, \mathrm{t}_{\mathrm{R}} 7.6 \mathrm{~min}\right)$, myricetin-3O-(6"-O-galloyl)- $\beta$-galactopyranoside $\left(\mathbf{1 3}, \mathrm{t}_{\mathrm{R}} 12.2 \mathrm{~min}\right)$, and myricetin $\left(\mathbf{1 7}, 4.1 \mathrm{mg}, \mathrm{t}_{\mathrm{R}} 17.3\right.$ min) were obtained. Final purification of 13 by semi-preparative HPLC was with 15\% $\mathrm{MeCN}$ in $0.05 \%$ aqueous formic acid (6.9 mg, $\left.\mathrm{t}_{\mathrm{R}} 9.5 \mathrm{~min}\right)$. 
Powdered leaves of $C$. aff. laxum $(197.7 \mathrm{~g}$ ) were percolated with $\mathrm{MeOH}(5 \mathrm{~L})$ to afford 13.2 $\mathrm{g}$ of extract. A portion (10.1 g) of the extract was redissolved in $200 \mathrm{~mL} \mathrm{MeOH}$ and submitted to polyamide $(200 \mathrm{~g})$ filtration. Four fractions (PA1-PA4) of $1 \mathrm{~L}$ each, and one fraction of $3 \mathrm{~L}$ (PA5) were collected. Fractions PA2, PA4, and PA5 were submitted to preparative HPLC. A portion $(500.0 \mathrm{mg})$ of fraction PA2 $(1036.4 \mathrm{mg})$ was separated with $25 \% \mathrm{MeCN}$ in $0.05 \%$ aqueous formic acid to afford myricitrin (15, $54.0 \mathrm{mg}, \mathrm{t}_{\mathrm{R}} 6.8 \mathrm{~min}$ ), mearnsitrin (19, $\left.0.64 \mathrm{mg}, \mathrm{t}_{\mathrm{R}} 9.5 \mathrm{~min}\right)$, and quercitrin (16, $\left.8.1 \mathrm{mg}, 9.8 \mathrm{~min}\right)$. Fraction PA4 (160.7 mg) was separated with $30 \% \mathrm{MeCN}$ in $0.05 \%$ aqueous formic acid to give 2"-Ogalloylmyricitrin (20, $\left.10.5 \mathrm{mg}, \mathrm{t}_{\mathrm{R}} 7.4 \mathrm{~min}\right), 3$ "-O-galloylmyricitrin (21, $\left.5.3 \mathrm{mg}, \mathrm{t}_{\mathrm{R}} 8.3 \mathrm{~min}\right), 2$ "O-galloylquercitrin $\left(22,6.9 \mathrm{mg}, \mathrm{t}_{\mathrm{R}} 10.5 \mathrm{~min}\right)$, and 3"-O-galloylquercitrin $(23,5.0 \mathrm{mg}, 11.9$ min). Fraction PA5 (785.6 mg) was separated with a gradient of $21-41 \% \mathrm{MeCN}$ in $0.05 \%$ aqueous formic acid over $30 \mathrm{~min}$ to afford ellagic acid (18, $\left.1.3 \mathrm{mg}, \mathrm{t}_{\mathrm{R}} 9.5 \mathrm{~min}\right), 20$ (10.0 $\left.\mathrm{mg}, \mathrm{t}_{\mathrm{R}} 14.3 \mathrm{~min}\right), 21$ (12.6 mg, $\left.15.2 \mathrm{~min}\right), 22$ (4.9 mg, $\left.18.0 \mathrm{~min}\right)$, and 23 (6.0 mg, $\left.19.1 \mathrm{~min}\right)$.

Powdered leaves of E. lucidum $(601.5 \mathrm{~g}$ ) were percolated with $\mathrm{MeOH}(11 \mathrm{~L})$ to give $77.3 \mathrm{~g}$ of extract. A portion $(20.3 \mathrm{~g})$ of the extract was redissolved in $200 \mathrm{~mL} \mathrm{MeOH}$ and submitted to polyamide $(200 \mathrm{~g})$ filtration. Four fractions (PA1-PA4) of $250 \mathrm{~mL}$ each, and one fraction (PA5) of $5 \mathrm{~L}$ were collected. A portion $(700.1 \mathrm{mg})$ of fraction PA3 $(2,183.2 \mathrm{mg})$ was submitted to preparative HPLC (gradient of $10-55 \% \mathrm{MeCN}$ in $0.05 \%$ aqueous formic acid over $20 \mathrm{~min})$ to afford quercitrin-7-O- $\alpha$-rhamnopyranoside $\left(26,20.1 \mathrm{mg}, \mathrm{t}_{\mathrm{R}} 10.2 \mathrm{~min}\right)$, rutin $\left(\mathbf{2 8}, 22.9 \mathrm{mg}, \mathrm{t}_{\mathrm{R}} 11.0 \mathrm{~min}\right)$, quercitrin $\left(\mathbf{1 6}, 13.1 \mathrm{mg}, \mathrm{t}_{\mathrm{R}} 13.2 \mathrm{~min}\right)$, and ombuin-3-O- $\beta$ rutinoside $\left(29,6.6 \mathrm{mg}, t_{R} 15.1 \mathrm{~min}\right)$. Two mixed fractions $\left(t_{R} 8.4 \mathrm{~min}\right.$ and $\left.t_{R} 10.5 \mathrm{~min}\right)$ were submitted to final purification by preparative HPLC to afford neochlorogenic acid $(\mathbf{2 4}, 6.2$ $\left.\mathrm{mg}, \mathrm{t}_{\mathrm{R}} 5.6 \mathrm{~min}\right)$, protocatechuic acid $\left(25,2.0 \mathrm{mg}, \mathrm{t}_{\mathrm{R}} 6.2 \mathrm{~min}\right), 26$ (2.1 mg, $\left.\mathrm{t}_{\mathrm{R}} 6.5 \mathrm{~min}\right)$, and 5 -O- $\beta$-glucopyranosylombuin-3-O- $\beta$-rutinoside $\left(27,8.2 \mathrm{mg}, \mathrm{t}_{\mathrm{R}} 7.5 \mathrm{~min}\right)$, respectively.

Compounds were identified with the aid of ${ }^{1} \mathrm{H}$ - and 2D-NMR, and ESI-MS spectroscopy, and by comparison with literature data. The purity of isolated compounds was $>95 \%$ as determined by NMR, except for compounds 3 (90\%), 4 (80\%), 25 (90\%), and 29 (80\%).

\section{Fungicidal Assay}

The activity against phytopathogenic fungi (Botryotinia fuckeliana, Magnaporthe oryzae, Phytophtora infestans, and Septoria tritici) could be demonstrated by the treatment of fungal spore suspensions and analysis of the growth in microplates using a robot system.

The tests were done in 96-well microtiter plates. Compounds were transferred as DMSO solutions into empty plates, followed by the addition of a spore suspension of the fungus of interest in a nutrient solution. Compounds were tested either in a single concentration, or as serial dilutions at 10 concentrations. Each plate contained eight solvent control wells and eight reference wells containing a known fungicide. The plates were incubated at $23^{\circ} \mathrm{C}$ and $90 \%$ relative humidity. Fungal growth was assessed by measuring the optical density at $620 \mathrm{~nm}$, immediately after treatment, and 10 times in intervals of 15 hours. In order to calculate the activity of a compound at a given concentration, the optical density values of each measurement of a compound was compared with those of the control and the reference, giving results from 0 to 1 , whereby higher values indicated higher activity. ED $D_{50}$ values were calculated with the aid of the dilution series. A compound having an activity ratio $\geq 0.75$, or an $E D_{50} \leq 10 \mathrm{mg} / \mathrm{l}$ was considered as active. 


\section{Insecticidal Assay}

Tested insect species were Anthonomus grandis, Heliothis virescens, Ceratitis capitata, Megoura viciae, and Myzus persicae. Insecticidal activity, either as a contact or systemic insecticide, against piercing/sucking insects (adults and offspring) was assessed in a test unit consisting of 24-well microtiter plates containing broad bean leaf disks. The compounds were formulated using a solution containing $75 \% \mathrm{v} / \mathrm{v}$ water and $25 \% \mathrm{v} / \mathrm{v}$ DMSO. Different concentrations of formulated compounds were sprayed onto the leaf disks at $2.5 \mu \mathrm{l}$, using a custom-built micro-atomizer. Two replicates were prepared. After application, leaf disks were air-dried, and 5-8 adult insects were placed onto the leaf disks placed into wells of a microtiter plate. Insects were then allowed to suck on the treated leaf disks, and were incubated at about $23 \pm 1^{\circ} \mathrm{C}$ and about $50 \pm 5 \%$ relative humidity for 5 days. Mortality was visually assessed.

Activity against biting insects (larvae) was evaluated in a test unit consisting of 24-well microtiter plates containing an insect diet and 20-30 insect eggs. Test compounds were formulated using a solution containing $75 \% \mathrm{v} / \mathrm{v}$ water and $25 \% \mathrm{v} / \mathrm{v}$ DMSO. Aliquots $(20 \mu \mathrm{l})$ of different concentrations of formulated compounds were sprayed onto the insect diet using a custom-built micro-atomizer. Two replicates were used. After application, microtiter plates were incubated for 5 days at $23 \pm 1^{\circ} \mathrm{C}$ and $50 \pm 5 \%$ relative humidity. Egg and larval mortality was then visually assessed. Compounds with $\geq 50 \%$ mortality in adult insects and larvae were considered as active.

\section{Herbicidal Assay}

Herbicidal activity was assessed on pre- and post-emergent Matricaria inodora, Agrostis stolonifera, and Poa annua. The culture containers used were plastic 96-well plates containing peat substrate. For the post-emergence treatment, the test plants, once they reached a height of $1-3 \mathrm{~cm}$ (depending on the plant species), were sprayed via a spray nozzle with the test compounds in 1,000 ppm DMSO solution. The application rate corresponded to $2 \mathrm{~kg} / \mathrm{ha}$, with an application volume of $200 \mathrm{~L} / \mathrm{ha}$. Plants were kept at $20-35^{\circ} \mathrm{C}$. The test period extended over 7 days. During this time, the plants were tended, and their response to the individual treatments was evaluated visually. The cutoff for herbicidal activity was $\geq 50 \%$ inhibition of growth (or $80 \%$ in the case of Matricaria inodora) of the treated weed, either pre- or post-emergence.

\section{Acknowledgement}

The work was carried out as part of the AGROCOS FP7 consortium project. Financial support by the European Commission is gratefully acknowledged. Mahabir P. Gupta also acknowledges SENACYT for support.

\section{Supporting Information}

A list of the 19 active extracts, additional activity profiles for $B$. frutescens, polyamide profiles of $M$. splendens, $C$. aff. laxum, and E. macrophyllum, and NMR data of compounds 1-8, 10, 12-17, and 19-29 are available in the online version (Type: PDF, Size: ca. 0.5 MB): http://dx.doi.org/10.3797/scipharm.1410-14 


\section{Authors' Statement}

\section{Competing Interests}

The authors declare no conflict of interest

\section{References}

[1] Copping LG, Duke SO.

Natural products that have been used commercially as crop protection agents.

Pest Manag Sci. 2007; 63: 524-554.

http://dx.doi.org/10.1002/ps.1378

[2] Thacker JRM.

An introduction to Arthropod Pest control.

Cambridge: Cambridge University Press, 2002.

[3] Cordell GA.

Biodiversity and drug discovery - a symbiotic relationship.

Phytochemistry. 2000; 55: 463-480.

http://dx.doi.org/10.1016/s0031-9422(00)00230-2

[4] Mittermeier RA, Gil PR, Pilgrim J.

Hotspots Revisited: Earth's Biologically Richest and Most Endangered Terrestrial Ecoregions.

Washington D.C.: Conservation International, 2005.

[5] Barthlott WB, Lauer W, Placke A.

Global distribution of species diversity in vascular plants: Towards a world map of phytodiversity. Erdkunde. 1996; 50: 317-327.

http://dx.doi.org/10.3112/erdkunde.1996.04.03

[6] Anonymous.

New map of "Biodiversity Hotspots" aids targeting of conservation efforts.

Diversity. 1997; 13: 27-29.

[7] D'Arcy WG.

Flora of Panama. Checklist and Index. Part I.

St. Louis: Missouri Botanical Garden, 1987.

[8] Correa MD, Galdames C, de Stapf MS.

Catálogo de las plantas vasculares de Panamá.

Panama: Editora Novo Art, SA, 2004.

[9] Gupta MP.

Panamanian Flora: source of bioactive compounds.

In: Hostettmann K, Marston A, Maillard M, Hamburger M; eds.

Phytochemistry of Plants used in traditional medicine.

Oxford: Clarendon Press, 1995: 359-398.

[10] Gupta MP, Marston A, Hostettmann K.

Bioactive compounds from Panamanian plants.

In: Hostettmann K, Gupta MP, Marston A; eds.

Chemistry, biological, and pharmacological properties of medicinal plants from the Americas.

Amsterdam: Harwood Academic Publishers, 1999: 143-159.

[11] Caballero-George C, Gupta MP.

A quarter century of pharmacognostic research on Panamanian flora: a review.

Planta Med. 2011; 77: 1189-1202.

http://dx.doi.org/10.1055/s-0030-1271187 
[12] Potterat O, Hamburger M.

Concepts and technologies for tracking bioactive compounds in natural product extracts: generation of libraries, and hyphenation of analytical processes with bioassays.

Nat Prod Rep. 2013; 30: 546-564.

http://dx.doi.org/10.1039/c3np20094a

[13] Potterat O, Hamburger M.

Combined Use of Extract Libraries and HPLC-Based Activity Profiling for Lead Discovery: Potential, Challenges, and Practical Considerations.

Planta Med. 2014; 80: 1171-1181.

http://dx.doi.org/10.1055/s-0034-1382900

[14] Miao F, Yang X-J, Zhou L, Hu H-J, Zheng F, Ding X-D, Sun D-M, Zhou C-D, Sun W. Structural modification of sanguinarine and chelerythrine and their antibacterial activity. Nat Prod Res. 2011; 25: 863-875. http://dx.doi.org/10.1080/14786419.2010.482055

[15] Ito M, Konno F, Kumamoto T, Suzuki N, Kawahata M, Yamaguchi K, Ishikawa T. Enantioselective synthesis of chelidonine, a B/C-cis-11-hydroxyhexahydrobenzo[c]phenanthridine alkaloid.

Tetrahedron. 2011; 67: 8041-8049.

http://dx.doi.org/10.1016/j.tet.2011.07.091

[16] Ishikawa $\mathrm{T}$, Saito $\mathrm{T}$, Ishii $\mathrm{H}$.

Synthesis of macarpine and its cytotoxicity: toward a synthetic route for 12-alkoxybenzo[c]phenanthridine alkaloids through aromatic nitrosation under basic condition.

Tetrahedron. 1995; 51: 8447-8458.

http://dx.doi.org/10.1016/0040-4020(95)00460-p

[17] Caballero-George C, Vanderheyden PML, Apers S, Van den Heuvel H, Solis PN, Gupta MP, Claeys M, Pieters L, Vauquelin G, Vlietinck AJ.

Inhibitory activity on binding of specific ligands to the human angiotensin II AT1 and endothelin 1 ETA receptors: Bioactive benzo[c]phenanthridine alkaloids from the root of Bocconia frutescens.

Planta Med. 2002; 68: 770-775.

http://dx.doi.org/10.1055/s-2002-34406

[18] Tani C, Takao S.

Studies on the alkaloids of fumariaceous plants. IX. Alkaloids of Bocconia frutescens.

Yakugaku Zasshi. 1967; 87: 699-701.

http://www.ncbi.nlm.nih.gov/pubmed/5624832

[19] Pasqua G, Silvestrini A, Monacelli B, Mulinacci N, Menendez P, Botta B.

Triterpenoids and ellagic acid derivatives from in vitro cultures of Camptotheca acuminata Decaisne.

Plant Physiol Biochem (Amsterdam, Neth). 2006; 44: 220-225.

http://dx.doi.org/10.1016/j.plaphy.2006.04.001

[20] Cho J-Y, Lee T-H, Hwang T-L, Yang S-Z, Chen I-S, Chou T-H, Sung P-J, Chen J-J.

A New Ferulic Acid Ester, a New Ellagic Acid Derivative, and Other Constituents from Pachycentria formosana: Effects on Neutrophil Pro-Inflammatory Responses.

Chem Biodivers. 2011; 8: 1709-1716.

http://dx.doi.org/10.1002/cbdv.201000228

[21] Ramesh AS, Christopher JG, Radhika R, Setty CR, Thankamani V.

Isolation, characterisation and cytotoxicity study of arjunolic acid fromTerminalia arjuna.

Nat Prod Res. 2012; 26: 1549-1552.

http://dx.doi.org/10.1080/14786419.2011.566870

[22] Masoko P, Mdee LK, Mampuru LJ, Eloff JN.

Biological activity of two related triterpenes isolated from Combretum/ nelsonii (Combretaceae) leaves.

Nat Prod Res. 2008; 22: 1074-1084.

http://dx.doi.org/10.1080/14786410802267494 
[23] Masoko P, Picard J, Howard RL, Mampuru LJ, Eloff JN.

In vivo antifungal effect of Combretum and Terminalia species extracts on cutaneous wound healing in immunosuppressed rats.

Pharm Biol 2010; 48: 621-632.

http://dx.doi.org/10.3109/13880200903229080

[24] Karonen M, Haemaelaeinen M, Nieminen R, Klika KD, Loponen J, Ovcharenko VV, Moilanen E, Pihlaja K.

Phenolic Extractives from the Bark of Pinus sylvestris L. and Their Effects on Inflammatory Mediators

Nitric Oxide and Prostaglandin E2.

J Agric Food Chem. 2004; 52: 7532-7540.

http://dx.doi.org/10.1021/jf048948q

[25] Khallouki F, Haubner R, Hull WE, Erben G, Spiegelhalder B, Bartsch H, Owen RW.

Isolation, purification and identification of ellagic acid derivatives, catechins, and procyanidins from the root bark of Anisophyllea dichostyla R. Br.

Food Chem Toxicol. 2007; 45: 472-485.

http://dx.doi.org/10.1016/j.fct.2006.09.011

[26] Kadota S, Takamori Y, Khin NN, Kikuchi T, Tanaka K, Ekimoto H.

Constituents of the leaves of Woodfordia fruticosa Kurz. I. Isolation, structure, and proton and carbon13 nuclear magnetic resonance signal assignments of woodfruticosin (woodfordin C), an inhibitor of deoxyribonucleic acid topoisomerase II.

Chem Pharm Bull. 1990; 38: 2687-2697.

http://dx.doi.org/10.1248/cpb.38.2687

[27] Korul'kina LM, Shul'ts EE, Zhusupova GE, Abilov ZA, Erzhanov KB, Chaudri MI.

Biologically active compounds from Limonium gmelinii and L. popovii. I.

Chem Nat Compd. 2004; 40: 465-471.

http://dx.doi.org/10.1007/s10600-005-0012-3

[28] Olaoluwa OO, Aiyelaagbe OO, Irwin D, Reid M.

Novel anthraquinone derivatives from the aerial parts of Antigonon leptopus Hook \& Arn.

Tetrahedron. 2013; 69: 6906-6910.

http://dx.doi.org/10.1016/j.tet.2013.05.014

[29] Castillo-Munoz N, Gomez-Alonso S, Garcia-Romero E, Gomez MV, Velders AH, Hermosin-Gutierrez I. Flavonol 3-O-Glycosides Series of Vitis vinifera Cv. Petit Verdot Red Wine Grapes.

J Agric Food Chem. 2009; 57: 209-219.

http://dx.doi.org/10.1021/jf802863g

[30] Yang Z-G, Jia L-N, Shen Y, Ohmura A, Kitanaka S.

Inhibitory Effects of Constituents from Euphorbia lunulata on Differentiation of 3T3-L1 Cells and Nitric Oxide Production in RAW264.7 Cells.

Molecules. 2011; 16: 8305-8318.

http://dx.doi.org/10.3390/molecules16108305

[31] Moresco HH, Pereira M, Bretanha LC, Micke GA, Pizzolatti MG, Brighente IMC.

Myricitrin as the main constituent of two species of Myrcia.

J App Pharm Sci. 2014; 4: 1-7.

http://dx.doi.org/10.7324/japs.2014.40201

[32] Masuda T, Someya T, Fujimoto A.

Phenolic Inhibitors of Chemical and Enzymatic Oxidation in the Leaves ofMyrica rubra.

Biosci Biotech Bioch. 2014; 74: 212-215.

http://dx.doi.org/10.1271/bbb.90697

[33] Peng ZF, Strack D, Baumert A, Subramaniam R, Goh NK, Chia TF, Tan SN, Chia LS.

Antioxidant flavonoids from leaves of Polygonum hydropiper $\mathrm{L}$.

Phytochemistry. 2003; 62: 219-228.

http://dx.doi.org/10.1016/s0031-9422(02)00504-6 
[34] Lin W-H, Deng Z-W, Lei H-M, Fu H-Z, Li J.

Polyphenolic compounds from the leaves of Koelreuteria paniculata Laxm.

J Asian Nat Prod Res. 2002; 4: 287-295.

http://dx.doi.org/10.1080/1028602021000049087

[35] Fan D-H, Wang H, Zhi D, Shen Y-M.

CE Analysis of Endogenous Flavonoid Gallate Esters from Nepenthes gracilis (Nepenthaceae).

Chromatographia. 2010; 72: 1013-1016.

http://dx.doi.org/10.1365/s10337-010-1729-0

[36] Mahmoud II, Marzouk MSA, Moharram FA, El-Gindi MR, Hassan AMK.

Acylated flavonol glycosides from Eugenia jambolana leaves.

Phytochemistry. 2001; 58: 1239-1244.

http://dx.doi.org/10.1016/s0031-9422(01)00365-x

[37] Pauli GF, Kuczkowiak U, Nahrstedt A.

Solvent effects in the structure dereplication of caffeoyl quinic acids.

Magn Reson Chem. 1999; 37: 827-836.

http://dx.doi.org/10.1002/(sici)1097-458x(199911)37:11<827::aid-mrc568>3.0.co;2-w

[38] Sefkow M, Kelling A, Schilde U.

First efficient syntheses of 1-, 4-, and 5-caffeoylquinic acid.

Eur J Org Chem. 2001: 2735-2742.

http://dx.doi.org/10.1002/1099-0690(200107)2001:14<2735::aid-ejoc2735>3.0.co;2-i

[39] Zhang JM, Shi XF, Ma QH, He FJ, Fan B, Wang DD, Liu DY.

Chemical constituents from pine needles of Cedrus deodara.

Chem Nat Compd. 2011; 47: 272-274.

http://dx.doi.org/10.1007/s10600-011-9901-9

[40] Chatterjee S, Variyar PS, Sharma A.

Stability of Lipid Constituents in Radiation Processed Fenugreek Seeds and Turmeric: Role of Phenolic Antioxidants.

J Agric Food Chem. 2009; 57: 9226-9233.

http://dx.doi.org/10.1021/j901642e

[41] González-Guevara JL, Vélez-Castro H, González-García KL, Payo-Hill AL, González-Lavaut JA, Molina-Torres J, Prieto-González S.

Flavonoid glycosides from Cuban Erythroxylum species.

Biochem Syst Ecol. 2006; 34: 539-542.

http://dx.doi.org/10.1016/j.bse.2006.01.003

[42] Zhang G, Guo M-L, Li R-P, Li Y, Zhang H-M, Su Z-W.

A novel compound from Flos carthami and its bioactivity.

Chem Nat Compd. 2009; 45: 398-401.

http://dx.doi.org/10.1007/s10600-009-9333-y 